\title{
Sesame meal as the first protein source in piglet starter diets and advantages of a phytase: a digestive study
}

\author{
T.C. Reis de Souza1, K. Escobar ${ }^{1}$, G. A. Aguilera', B. E. Ramírez², R. G. Mariscal-Landín ${ }^{2 \#}$ \\ ${ }^{1}$ Facultad de Ciencias Naturales, Universidad Autónoma de Querétaro, Av. De las Ciencias s/n, Santiago de Querétaro, \\ Querétaro 76230 México \\ ${ }^{2}$ Centro Nacional de Investigación en Fisiología Animal, Instituto Nacional de Investigaciones Forestales Agrícolas y \\ Pecuarias, km 1 Carretera a Colón, Ajuchitlán Colón, Querétaro 76280 México
}

(Received 2 March; Accepted 12 May 2017; First published online 5 August 2017)
Copyright resides with the authors in terms of the Creative Commons Attribution 4.0 South African License.
See: http://creativecommons.org/licenses/by/4.0/za
Condition of use: The user may copy, distribute, transmit and adapt the work, but must recognize the authors and the South African Journal of Animal Science.

\begin{abstract}
Soybean meal (SBM) is the protein source that is used most in feeding piglets, but its high price has prompted a search for alternatives. One option is sesame meal (SM), a by-product of sesame oil. This study evaluated the effects of SM and phytase on the intestinal morphology, total trypsin activity (TTA) and specific trypsin activity (STA), apparent ileal digestibility (AID) of amino acids (AAs), and apparent total tract digestibility (ATTD) of phosphorus (P), calcium (Ca), and energy $(E)$ in weaned piglets. Twenty piglets weaned at 17 days old were placed in metabolic cages in a temperature-controlled room. When the piglets were 21 days old, cannulas were fitted at the terminal ileum. From the fourth day after surgery, piglets received the experimental treatments for nine days, namely an SM or SBM diet, each with or without phytase. The protein source or phytase did not affect villus height, crypt depth, or TTA. However, phytase increased STA. The AID of dry matter (DM), E, crude protein (CP), and AA was similar among treatments, except for arginine, which was more digestible in the SM diets (85.8) than in the SBM ones (81.6). The ATTD of DM and E was higher in the SM than in the SBM diets. Phytase increased the ATTD of Ca $(22.7 \%)$ and P $(27.9 \%)$. The findings showed that SM can be used as a protein source for piglets and that its consumption increases arginine intake. The addition of phytase to the diet increases the ATTD of P and Ca.
\end{abstract}

Keywords: Amino acids digestibility, arginine, piglets weaning, phosphorus digestibility

\#Corresponding author: mariscal.gerardo@inifap.gob.mx

\section{Introduction}

The transition from milk to a starter diet at weaning can challenge the digestive tract of piglets (Montagne et al., 2004), because starter diets contains fewer digestible ingredients than milk (Gilani et al., 2012). Piglets in particular have lower digestive enzyme activity in their immature gastrointestinal tract. Consequently, in the days immediately following weaning, anorexia and undernutrition are often observed, which makes weaning a critical phase for piglets (Reis de Souza \& Mariscal-Landín, 1997). For these reasons, it is important to offer feeds of high nutritional quality during this period.

Soybean meal (SBM) is the most common protein source for pigs, but its high price has prompted the need to find alternative sources of this nutrient. One such option is sesame meal (SM), which is a by-product of the growing manufacture of sesame oil for human consumption (Avilés et al., 2009). Sesame seeds contain $15-20 \%$ CP, $26 \%$ carbohydrates, $45-50 \%$ ether extract, and are rich in methionine, oleic and linoleic acids, and calcium (Ca). Pressed sesame meal CP varies between 45 and $50 \%$, and ether extract content is close to $10-12 \%$ or $1-2 \%$ when a solvent is used (Sato et al., 2004; Yamuchi et al., 2006). However, SM has a high phytate content that chelates lipids, proteins, and minerals, forming insoluble fractions that are inaccessible to the animal (Ravindran et al., 1994). Adding an exogenous phytase to the diet increases the digestibility of $\mathrm{P}$ and the fractions associated with the phytate, and decreases nutrient loss through the faeces (Lei \& Stahl, 2001).

The objectives of this study were i) to evaluate SM as an alternative feed for weaned piglets and test the impact of an exogenous phytase on intestinal morphology (villus height and crypt depth), trypsin activity and AID of protein, AAs, E, P and Ca; and ii) to assess the ATTD of protein, E, P and Ca. 


\section{Materials and methods}

All experimental procedures were reviewed and approved by the Bioethics Committee of the Faculty of Natural Sciences of the Autonomous University of Querétaro, México. (Resolution FNV 201306). Piglets were handled according to guidelines described by the Mexican Official Standard for the Production, Protection, and Use of Laboratory Animals (Diario Oficial de la Federación, 2001) and International Guiding Principles for Biomedical Research Involving Animals (CIOMS, 1985).

Twenty piglets (Genetiporc, Fertilis $25 \times$ G Performance 8 ), weaned at $17 \pm 1$ days old and weighing $7.1 \pm 1.31 \mathrm{~kg}$, were used in the experiment. The piglets were placed in individual metabolic cages in a temperature controlled room $\left(26 \pm 3^{\circ} \mathrm{C}\right)$ and provided with self-feeders and low-pressure drinking nipples. To minimally modify the enzymatic profile of suckling animals, piglets were fed a mixture of dry whole milk $(80 \%)$ and maize starch (20\%) from 18 to 20 days old. Feedings were provided at 08:00, 13:00, and 18:00, and piglet feed intake was $30 \mathrm{~g} / \mathrm{kg}$ bodyweight. When the piglets were 21 days old, a T-cannula was placed at the terminal ileum, according to the method of Reis de Souza et al. (2000). After surgery, antibiotics were administered for three days (penicillin 600,000 IU, streptomycin $750 \mathrm{mg}$, and oxytetracycline $500 \mathrm{mg}$ ).

From the day after surgery and for the next four days, the piglets received a milk diet that was mixed with the experimental diets in the following ratios (milk diet : experimental): $100: 0,75: 25,50: 50$, and 0 : 100. From the fourth day after surgery, the piglets received one of four experimental diets during a nine-day study period. The diets consisted of SM or SBM, both with or without phytase (Ronozyme ${ }^{\circledR}$, HiPhos, DSM Nutritional Products ${ }^{\circledR}$ ) (Table 1). All experimental diets contained $200 \mathrm{~g} / \mathrm{kg}$ protein source (SM or SBM). To optimize $\mathrm{Ca}$ and $\mathrm{P}$ utilization, the dietary ratio was adjusted between $1.2: 1$ and $1: 1$, as recommended by Braña et al. (2006). Salt, vitamins, and mineral premixes were supplemented at levels that met or exceeded NRC nutritional requirements (NRC, 2012). Titanium oxide was added at a rate of $3 \mathrm{~g} / \mathrm{kg}$ feed as an inert marker.

Experimental diets were provided during the study period (13 days), according to the above schedules (Table 1). The piglets had free access to water. The experimental period consisted of nine days for adaptation, two days for faeces collection, and two days for sampling ileal digesta. The faeces were frozen and stored at $-20^{\circ} \mathrm{C}$. At the end of the experimental period, the faeces were defrosted and homogenized, and one aliquot of $10 \%$ of the weight was taken as the final sample. Ileal digesta was collected in plastic bags $(5 \mathrm{~cm} \times 3 \mathrm{~cm})$ containing $2 \mathrm{~mL}$ of a $0.2 \mathrm{~mol} / \mathrm{L} \mathrm{HCl}$ solution to inhibit bacterial activity. Bags were attached to the barrel of the cannula with a rubber band. lleal digesta was collected continuously over 12 hours (08:00 to 20:00) on days 12 and 13 after surgery. When the bags were filled with ileal digesta, they were transferred to a container and frozen at $-20^{\circ} \mathrm{C}$ until lyophilization.

At the end of the experiment, $\mathrm{CO}_{2}$ inhalation was used to induce narcosis in the piglets, and they were euthanized by exsanguination. A midline incision was made in the abdomen to expose the digestive tract. The small intestine was removed from the abdominal cavity and divided into the duodenum, jejunum, and ileum. Each part was emptied and weighed, and an approximately $10 \mathrm{~cm}$ portion was taken (Reis de Souza et al., 2005). These segments were washed with saline solution and perfused with $10 \%$ neutralized formalin. Forty-eight hours after collection, the intestinal samples were embedded in paraffin and cut to five microns thick. The cuts were stained with haematoxylin-eosin and observed under a microscope. Ten measurements per sheet were made to determine the average villus height (apex to base) and crypt depth (the base of the villi to the bottom of the crypt). The pancreas was then excised, dissected from connective tissue, weighed, frozen immediately in liquid nitrogen $(\mathrm{N})$ and stored at $-80^{\circ} \mathrm{C}$.

The faeces were partially dried at $55^{\circ} \mathrm{C}$ using an oven with circulating air and the digesta were lyophilized. All samples (raw materials, experimental diets, ileal digesta, and faeces) were ground in a laboratory mill with a $0.5-\mathrm{mm}$ mesh (Arthur $\mathrm{H}$. Thomas Co. Philadelphia, Pa). Raw materials, experimental diets, ileal digesta, and faeces were analysed for DM and CP, according to AOAC methods 934.01 and 976.05 (AOAC, 2000), respectively. Titanium oxide was measured according to the method reported by Myers et al. (2004). Sample preparation for AA analysis was performed following method 994.12 of AOAC (2000). Samples were hydrolysed in $6 \mathrm{M} \mathrm{HCl}$ at $110^{\circ} \mathrm{C}$ for 24 hours. Amino acid analysis was carried out according to the method reported by Henderson et al. (2000). Methionine, cystine, and tryptophan were not analysed. $\mathrm{Ca}$ and $\mathrm{P}$ concentrations were determined in duplicate with inductively coupled plasma atomic emission spectroscopy using the Application Note: 40755 (Harper) on Thermo Scientific (iCAP 6000 Series ICP) apparatus. The ashes had previously beendigested with a solution of nitric and per chloric acids according the method reported by (Harper). The wavelengths used were $178.284 \mathrm{~nm}$ for $\mathrm{P}$ and $317.933 \mathrm{~nm}$ for $\mathrm{Ca}$. 
Table 1 Formulation and nutrient composition of experimental diets ( $\mathrm{g} / \mathrm{kg}$, as-fed basis).

\begin{tabular}{|c|c|c|c|c|}
\hline & \multicolumn{2}{|c|}{ Sesame Meal } & \multicolumn{2}{|c|}{ Soybean Meal } \\
\hline & Without & With & Without & With \\
\hline \multicolumn{5}{|l|}{ Ingredients } \\
\hline Yellow corn & 555.5 & 555.4 & 518.1 & 518.0 \\
\hline Sesame meal & 200.0 & 200.0 & & \\
\hline Soybean meal & & & 200.0 & 200.0 \\
\hline Soybean concentrate & 22.2 & 22.2 & 49.1 & 49.1 \\
\hline Whey milk & 178.3 & 178.3 & 178.3 & 178.3 \\
\hline Corn mil & 6.2 & 6.2 & 16.5 & 16.5 \\
\hline Fibre $^{1}$ & 8.0 & 8.0 & 8.0 & 8.0 \\
\hline L-Lysine HCL & 9.4 & 9.4 & 4.2 & 4.2 \\
\hline L Threonine & 1.6 & 1.6 & 1.2 & 1.2 \\
\hline L Tryptophan & 0.2 & 0.2 & 0.4 & 0.4 \\
\hline DL Methionine & & & 0.7 & 0.7 \\
\hline Salt & 7.0 & 7.0 & 7.0 & 7.0 \\
\hline Dicalcium phosphate & 3.2 & 3.2 & 4.4 & 4.4 \\
\hline Calcium carbonate & & & 3.7 & 3.7 \\
\hline Enzyme $^{2}$ & & 0.1 & & 0.1 \\
\hline Flavoring $^{3}$ & 2.0 & 2.0 & 2.0 & 2.0 \\
\hline Vitamins $^{4}$ & 2.2 & 2.2 & 2.2 & 2.2 \\
\hline Minerals ${ }^{5}$ & 1.2 & 1.2 & 1.2 & 1.2 \\
\hline Titanium oxide & 3.0 & 3.0 & 3.0 & 3.0 \\
\hline \multicolumn{5}{|c|}{ Chemical analysed composition } \\
\hline Dry matter \% & 88.8 & 90.3 & 90.1 & 90.2 \\
\hline Crude protein \% & 21.2 & 21.0 & 20.7 & 19.2 \\
\hline $\mathrm{ME} \mathrm{Kcal/ \textrm {kg } ^ { 6 }}$ & 3238 & 3264 & 3220 & 3248 \\
\hline NDF \% & 11.4 & 10.5 & 8.5 & 8.7 \\
\hline ADF \% & 2.5 & 2.2 & 1.7 & 1.7 \\
\hline Calcium & 0.60 & 0.60 & 0.63 & 0.63 \\
\hline Phosphorus & 0.63 & 0.63 & 0.51 & 0.51 \\
\hline
\end{tabular}

${ }^{1}$ Arbocel® crude fibre concentrate, J. Rettenmaier \& Söhne Group

${ }^{2}$ Ronozyme Hyphos GT® DS (this amount provides $1000 \mathrm{FTU} / \mathrm{kg}$ feed)

${ }^{3}$ Gustor®, sodium butyrate, NOREL Animal Nutrition

${ }^{4}$ Vitamin premix per kg of feed: vit a, 10,200 iu; vit e, 60 iu; vit d, 1980 iu; vit k, 1.2 mg; biotin, 0.08 mg; folacin, 0.75 mg; niacin, $36 \mathrm{mg}$; pantothenic acid, $16.55 \mathrm{mg}$; riboflavin, $7.2 \mathrm{mg}$; thiamin, $0.30 \mathrm{mg}$; $b_{6}, 0.31 \mathrm{mg}$; $b_{12}, 0.04 \mathrm{mg}$;

${ }^{5}$ Mineral premix per kg of feed: cobalt, $0.72 \mathrm{mg}$; copper, $14.40 \mathrm{mg}$; iodine, $0.96 \mathrm{mg}$; iron, $120 \mathrm{mg}$; manganese, $36 \mathrm{mg}$; selenium, $0.30 \mathrm{mg}$; zinc, $144 \mathrm{mg}$

${ }^{6}$ Estimated from INRA tables (INRA, 2002)

Protein determination in pancreatic tissue was undertaken using the technique by Lowry et al. (1951). Specific activity (substrate $\mu \mathrm{mol}$ released per minute per $\mathrm{mg}$ of protein) and total activity (substrate $\mu \mathrm{mol}$ released per minute per $\mathrm{g}$ of tissue or digesta) of trypsin were determined following the method of Reboud et al. (1962).

AID and ATT) were estimated using the following equation (Fan et al., 1994):

AID or $A T T D=[1-[(I D \times A F) /(A D \times I F)]] * 100$

Where: AID or ATTD = apparent digestibility (ileal or total tract) of a nutrient in the diet $I D=$ concentration of the marker in the diet $(\mathrm{mg} / \mathrm{kg} \mathrm{DM})$ 
$\mathrm{AF}=$ concentration of the nutrient in ileal digesta or faeces $(\mathrm{mg} / \mathrm{kg} \mathrm{DM})$

$A D=$ concentration of the nutrient in the diet $(\mathrm{mg} / \mathrm{kg} \mathrm{DM})$

$\mathrm{IF}=$ concentration of the marker in the ileal digesta or faeces $(\mathrm{mg} / \mathrm{kg} \mathrm{DM})$

Homogeneity of variance for all data was tested using Levene's test with the HOVTEST of SAS software (SAS version 9.2, 2008). The data from all variables (AID, ATTD, villus height, crypts depth, STA, and TTA) were analysed as a completely randomized block design with a $2 \times 2$ factorial arrangement, using the GLM procedure of SAS software (SAS version 9.2, 2008). The piglets were the experimental units for all the variables. Treatment means were compared using the Duncan method, and an $\alpha$-value of 0.05 was used to assess significance (Steel \& Torrie, 1980).

\section{Results}

There was no effect $(P>0.10)$ of treatments on villi height and crypt depth in any intestinal portion (Table 2). The average villi height of piglets fed SM in the duodenum was $515 \mu \mathrm{m}, 377 \mu \mathrm{m}$, in the jejunum, and $332 \mu \mathrm{m}$ in the ileum; and for those fed SBM was 582, 423, and $370 \mu \mathrm{m}$ in the duodenum, jejunum, and ileum respectively. The average crypt depth of piglets fed SM in the duodenum was $133 \mu \mathrm{m}, 132 \mu \mathrm{m}$ in jejunum, and $129 \mu \mathrm{m}$ in ileum; and for those fed SBM was 138, 128, and $137 \mu \mathrm{m}$ in the duodenum, jejunum and ileum, respectively.

Table 2 Effect of protein source: Soybean meal or Sesame meal; or phytase enzyme: added or non-added on measures of intestinal villi of duodenum, jejunum, and ileum of piglets (in $\mathrm{mm}$ ).

\begin{tabular}{|c|c|c|c|c|c|c|c|}
\hline \multirow{2}{*}{ Main Factors } & \multicolumn{2}{|c|}{ Source } & \multicolumn{2}{|c|}{ Enzyme } & \multicolumn{2}{|r|}{ Source } & \multirow{2}{*}{$\begin{array}{c}\text { Enzyme } \\
P\end{array}$} \\
\hline & $\mathrm{SM}^{1}$ & $\mathrm{SBM}^{2}$ & Without & With & $\mathrm{SEM}^{3}$ & $P^{4}$ & \\
\hline \multicolumn{8}{|l|}{ Duodenum } \\
\hline Villi height & 515 & 582 & 588 & 528 & 51.2 & 0.99 & 0.76 \\
\hline Crypt depth & 128 & 138 & 127 & 138 & 7.4 & 0.17 & 0.85 \\
\hline \multicolumn{8}{|l|}{ Jejunum } \\
\hline Villi height & 377 & 423 & 407 & 400 & 26.6 & 0.62 & 0.59 \\
\hline Crypt depth & 134 & 128 & 131 & 130 & 10.0 & 0.70 & 0.93 \\
\hline \multicolumn{8}{|l|}{ Ileum } \\
\hline Villi height & 332 & 370 & 329 & 373 & 35.3 & 0.26 & 0.89 \\
\hline Crypt depth & 120 & 137 & 130 & 130 & 8.9 & 0.28 & 0.85 \\
\hline \multicolumn{8}{|l|}{ Treatments } \\
\hline Source & \multicolumn{2}{|c|}{ SM } & \multicolumn{2}{|c|}{ SBM } & SEM & Interaction & \\
\hline Enzyme & Without & With & Without & With & & $P$ & \\
\hline \multicolumn{8}{|l|}{ Duodenum } \\
\hline Villi height & 493 & 528 & 636 & 528 & 39.1 & 0.34 & \\
\hline Crypt depth & 126 & 129 & 128 & 148 & 5.6 & 0.42 & \\
\hline \multicolumn{8}{|l|}{ Jejunum } \\
\hline Villi height & 356 & 388 & 433 & 413 & 20.1 & 0.50 & \\
\hline Crypt depth & 136 & 134 & 129 & 127 & 7.6 & 0.99 & \\
\hline \multicolumn{8}{|l|}{ Ileum } \\
\hline Villi height & 325 & 336 & 331 & 410 & 26.7 & 0.51 & \\
\hline Crypt depth & 118 & 122 & 136 & 139 & 6.7 & 0.99 & \\
\hline
\end{tabular}

\footnotetext{
Sesame meal

${ }^{2}$ Soybean meal

${ }^{3}$ Standard error of $m$ meal

${ }^{4}$ Probability of a level
} 
There was no effect $(P>0.10)$ of treatments on TTA (Table 3). The value for piglets fed SM was 3921 $\mathrm{IU} / \mathrm{g}$ of tissue; and for those fed SBM was $3961 \mathrm{IU} / \mathrm{g}$ of tissue. The STA was affected $(P<0.05)$ by protein source. The values were 66.7 and $55.4 \mathrm{IU} / \mathrm{mg}$ of tissue for animals fed the SM and SBM, diets respectively. However, no effect $(P>0.10)$ was observed between the animals fed diets without phytase and those fed diets with phytase 64.1 and $58.1 \mathrm{IU} / \mathrm{mg}$ protein, respectively.

Table 3 Effect of protein source: Soybean meal or Sesame meal; or phytase enzyme: added or non-added on Specific and Total Trypsin Activity.

\begin{tabular}{|c|c|c|c|c|c|c|c|}
\hline \multirow{2}{*}{ Main Factors } & \multicolumn{2}{|c|}{ Source } & \multicolumn{2}{|c|}{ Enzyme } & \multicolumn{2}{|r|}{ Source } & \multirow{2}{*}{$\begin{array}{r}\text { Enzyme } \\
P\end{array}$} \\
\hline & $\mathrm{SM}^{1}$ & SBM $^{2}$ & Without & With & SEM $^{3}$ & $P^{4}$ & \\
\hline Total activity $^{\mathrm{a}}$ & 3921 & 3961 & 3994 & 3888 & 168.0 & 0.87 & 0.67 \\
\hline Specific activity ${ }^{\mathrm{b}}$ & 66.7 & 55.4 & 64.1 & 58.1 & 3.8 & 0.05 & 0.28 \\
\hline \multicolumn{8}{|l|}{ Treatments } \\
\hline Source & \multicolumn{2}{|c|}{ SM } & \multicolumn{2}{|c|}{ SBM } & SEM & Interaction & \\
\hline Enzyme & Without & With & Without & With & & $P$ & \\
\hline Total activity & 4155 & 3688 & 3833 & 4089 & 135.4 & 0.16 & \\
\hline Specific activity & 74.2 & 59.3 & 54.0 & 56.8 & 3.02 & 0.12 & \\
\hline
\end{tabular}

\footnotetext{
${ }^{1}$ Sesame meal

${ }^{2}$ Soybean meal

${ }^{3}$ Standard error of the mean

${ }^{4}$ Probability of a level

${ }^{\text {a }}$ Total enzyme activity (IU/g of tissue)

${ }^{b}$ Specific enzyme activity (IU/mg of protein)
}

Protein source did not affect $(P>0.05)$ the AID of any nutrient. The average AID of DM was 72.3, E 73.6, protein 77.7 (Table 4). The least digestible AA was histidine (53.6 and 59.6 in SM and SBM, respectively). Arginine was the most digestible amino acid in SM (85.8). It was more digestible $(P<0.001)$ than in SBM diets (81.6). The most digestible AA in the SBM diet was lysine (83.7) and its digestibility was similar $(P>0.05)$ to that observed in the SM diet (82.7). The protein source did not affect $(P>0.05)$ the Ca and P AID. However, the ATTD of DM and $E$ was higher $(P<0.05)$ in SBM diets $(86.4 ; 86.2)$ than in SM diets (84.4; 84.0), respectively (Table 5$)$.

Phytase addition did not affect $(P>0.05)$ the AID of DM, CP and E. However, it improved significantly $(P<0.001)$ the AID of $\mathrm{Ca}$, and $\mathrm{P}$ (Tables 4 and 5). At faecal level (Table 6), the enzyme did not affect $(P$ $>0.05)$ the ATTD of DM (85.4), protein (81.5), and E (85.1). There was a trend to be significant $(P<0.06)$ the interaction for the ATTD of DM, because there was an increment from 83.9 to 86.1 in Sesame Meal Dry Matter Apparent Total Tract Digestibility when phytase was added to the diet and a decrement from 87.1 to 86.3 in Soybean Meal diet. Phytase increased significantly $(P<0.001)$ the ATTD of Ca 22.7\%, and P $27.9 \%$. 
Table 4 Effect of protein source: Soybean meal or Sesame meal; or phytase enzyme: added or non-added on Apparent lleal Digestibility.

\begin{tabular}{|c|c|c|c|c|c|c|c|c|c|c|c|c|c|}
\hline \multirow{2}{*}{ Main Factors } & \multicolumn{2}{|c|}{ Source } & \multicolumn{2}{|c|}{ Enzyme } & \multicolumn{2}{|r|}{ Source } & \multirow{2}{*}{$\begin{array}{c}\text { Enzyme } \\
P\end{array}$} & \multicolumn{2}{|c|}{ Sesame Meal } & \multicolumn{2}{|c|}{ Soybean Meal } & \multicolumn{2}{|c|}{ Interaction } \\
\hline & $\mathrm{SM}^{1}$ & $\mathrm{SBM}^{2}$ & Without & With & SEM $^{3}$ & $P^{4}$ & & Without & With & Without & With & SEM & $P$ \\
\hline Dry matter & 71.1 & 73.4 & 71.0 & 73.4 & 1.37 & 0.20 & 0.21 & 69.4 & 73.1 & 74.6 & 73.6 & 1.82 & 0.17 \\
\hline Protein & 77.4 & 78.0 & 77.5 & 77.9 & 0.88 & 0.63 & 0.70 & 76.4 & 77.4 & 78.8 & 77.1 & 1.44 & 0.23 \\
\hline Energy & 72.7 & 74.5 & 73.1 & 74.1 & 1.10 & 0.19 & 0.54 & 72.5 & 73.0 & 75.6 & 75.0 & 1.47 & 0.66 \\
\hline \multicolumn{14}{|l|}{ Amino acids } \\
\hline Alanine & 67.6 & 68.5 & 68.0 & 68.1 & 1.62 & 0.69 & 0.98 & 68.3 & 66.9 & 68.2 & 69.5 & 2.17 & 0.50 \\
\hline Aspartic acid & 74.4 & 74.5 & 73.4 & 75.5 & 1.61 & 0.98 & 0.37 & 74.4 & 74.0 & 73.7 & 76.0 & 2.16 & 0.49 \\
\hline Arginine & 85.8 & 81.6 & 83.7 & 83.7 & 0.97 & 0.01 & 0.97 & 86.9 & 85.4 & 82.2 & 81.8 & 1.30 & 0.65 \\
\hline Glutamic acid & 83.8 & 83.1 & 83.1 & 83.8 & 0.95 & 0.52 & 0.62 & 83.8 & 83.2 & 83.2 & 83.1 & 1.28 & 0.81 \\
\hline Glycine & 60.8 & 59.8 & 61.1 & 59.5 & 2.24 & 0.72 & 0.60 & 62.5 & 59.0 & 60.5 & 58.6 & 3.00 & 0.76 \\
\hline Histidine & 53.6 & 59.6 & 55.8 & 57.4 & 2.75 & 0.14 & 0.66 & 49.0 & 56.7 & 60.3 & 55.3 & 3.70 & 0.08 \\
\hline Isoleucine & 76.1 & 77.6 & 76.6 & 77.2 & 1.28 & 0.36 & 0.74 & 75.9 & 75.6 & 77.0 & 79.1 & 1.71 & 0.45 \\
\hline Leucine & 77.9 & 78.1 & 77.2 & 78.8 & 1.08 & 0.92 & 0.30 & 77.5 & 78.7 & 77.8 & 80.2 & 1.45 & 0.65 \\
\hline Lysine & 82.7 & 83.7 & 82.9 & 83.5 & 1.02 & 0.45 & 0.68 & 83.6 & 81.7 & 83.4 & 84.9 & 1.47 & 0.20 \\
\hline Phenylalanine & 80.7 & 78.5 & 78.5 & 80.7 & 1.22 & 0.18 & 0.22 & 79.6 & 81.8 & 78.4 & 80.1 & 1.63 & 0.85 \\
\hline Proline & 66.8 & 69.8 & 69.1 & 67.4 & 3.18 & 0.46 & 0.71 & 67.8 & 63.6 & 68.5 & 69.9 & 4.28 & 0.49 \\
\hline Serine & 74.3 & 74.3 & 73.6 & 74.9 & 1.31 & 0.96 & 0.48 & 74.4 & 74.3 & 74.3 & 75.4 & 1.75 & 0.73 \\
\hline Threonine & 73.8 & 73.5 & 73.4 & 74.0 & 1.33 & 0.87 & 0.74 & 73.5 & 74.6 & 74.7 & 73.7 & 1.77 & 0.54 \\
\hline Tyrosine & 76.0 & 75.2 & 75.0 & 76.7 & 1.47 & 0.69 & 0.28 & 76.5 & 76.5 & 74.5 & 77.6 & 1.96 & 0.40 \\
\hline Valine & 82.5 & 82.8 & 81.9 & 83.4 & 1.05 & 0.79 & 0.30 & 82.8 & 82.8 & 82.3 & 84.5 & 1.41 & 0.41 \\
\hline Calcium & 73.3 & 63.5 & 50.5 & 81.3 & 4.55 & 0.32 & 0.001 & 61.7 & 81.3 & 43.7 & 81.3 & 5.10 & 0.28 \\
\hline Phosphorus & 56.8 & 62.2 & 49.3 & 69.7 & 4.03 & 0.26 & 0.001 & 43.0 & 68.4 & 54.5 & 69.9 & 3.08 & 0.36 \\
\hline
\end{tabular}

${ }^{1}$ Sesame meal

${ }^{3}$ Standard error of $m$ meal

${ }^{4}$ Probability of a level 


\section{Discussion}

Because the experimental starter diets were the first feeds that were offered to the piglets after weaning, it was important to use ingredients that were highly digestible and then only gradually to make changes to conventional ingredients (Kim \& Hansen, 2013). For these reasons, the contents of SM and SBM were limited to $20 \%$ of the experimental diet. The lack of an effect of diet on villus height and crypt depth could be because of the time that had elapsed between weaning and obtaining the samples obtained. This time corresponds to the adaptation period of the gut to the weaning diet and in this period the main factors of this adaptation are the re-feeding and the time, while the diet per se had little influence (Montagne et al., 2007). Feed intake ensures the presence of nutrients at lumen level, which has a positive effect on the structural development of the mucosa. This lack of influence of sesame on gut disturbances has been observed (Aguilera et al., 2014), and could be related to the quality of SM, because it had a similar digestibility to SBM.

The interactions between negatively charged phytate molecules and protein are favoured in the presence of basic AAs (arginine, histidine and lysine) when the $\mathrm{pH}$ is below to the isoelectric point of the protein, which prompts the formation of insoluble macromolecular aggregates (Selle et al., 2012). The $\alpha$ globulin from SM is rich in arginine and its isoelectric point is 4.5, so meets these two characteristics. The formation of this precipitate may have required a greater amount of trypsin to digest it, which would explain the greater STA observed in animals fed the SM diets (Selle et al., 2012).

Table 5 Effect of protein source: Soybean meal or Sesame meal; or phytase enzyme: added or non-added on Apparent Total Tract Digestibility.

\begin{tabular}{lccccccc}
\hline \multirow{2}{*}{ Main Factors } & \multicolumn{2}{c}{ Source } & \multicolumn{2}{c}{ Enzyme } & & Source & Enzyme \\
\cline { 2 - 8 } & SM $^{\mathbf{1}}$ & SBM $^{\mathbf{2}}$ & Without & With & SEM $^{\mathbf{3}}$ & $\boldsymbol{P}^{\mathbf{4}}$ & $\boldsymbol{P}$ \\
\hline Dry matter & 84.4 & 86.4 & 84.9 & 85.8 & 1.89 & 0.04 & 0.44 \\
Protein & 80.9 & 82.2 & 81.0 & 82.0 & 2.10 & 0.25 & 0.49 \\
Energy & 84.0 & 86.2 & 85.5 & 84.7 & 0.67 & 0.02 & 0.39 \\
Calcium & 68.4 & 65.1 & 53.9 & 79.6 & 3.93 & 0.51 & 0.001 \\
Phosphorus & 59.0 & 61.7 & 46.4 & 74.3 & 4.07 & 0.61 & 0.001
\end{tabular}

Treatments

Source

Enzyme

$\begin{array}{lllllll}\text { Dry matter } & 83.9 & 86.1 & 87.1 & 86.3 & 0.60 & 0.06 \\ \text { Protein } & 80.5 & 81.8 & 82.2 & 82.6 & 0.86 & 0.70 \\ \text { Energy } & 84.3 & 83.7 & 86.7 & 85.7 & 0.67 & 0.81 \\ \text { Calcium } & 57.2 & 79.6 & 50.6 & 79.6 & 3.94 & 0.50 \\ \text { Phosphorus } & 46.8 & 71.2 & 46.0 & 77.3 & 4.08 & 0.50\end{array}$

\footnotetext{
${ }^{1}$ Sesame meal

${ }^{2}$ Soybean meal

${ }^{3}$ Standard error of $\mathrm{m}$ meal

${ }^{4}$ Probability of a level
}

A high-protein diet induces pancreatic growth and the production of pancreatic proteases (Hara et al., 2001; Montagne et al., 2007). A possible explanation for this effect is that dietary protein in the lumen of the small intestine competes with endogenous Cholecystokinin (CCK)-releasing peptide factors for hydrolysis by pancreatic proteases, which results in the prolonged survival of CCK-releasing peptides (Hara et al., 2001).

This mechanism could explain the STA levels in diets with and without the phytase enzyme, because several reports showed that phytase increases protein and AA ileal digestibility (Selle \& Ravindran, 2008; 
Gilani et al., 2012; Selle et al., 2012; Dersjant-Li et al., 2015). Additionally, this could increase the hydrolysis of the endogenous CCK-releasing peptide factors by diminishing their stimuli on the pancreas, even if this has not been reflected in AA ileal digestibility. The similar apparent ileal digestibility among diets could be explained by two factors: the four diets had the same ingredients (yellow corn, soybean meal concentrate, whey milk, and crystalline AAs); and the quality of the meals, because SBM and SM have similar digestibility (Aguilera et al., 2015). This characteristic highlights the potential importance of SM as a protein source for piglets at weaning. Weaning is characterized by low feed intake, which causes loss of mucosal integrity (Reis de Souza \& Mariscal-Landín, 1997; Reis de Souza et al., 2005; Reis de Souza et al., 2007). This deterioration reduces the ability of the small intestine to export citrulline, which affects the synthesis of arginine in the body and prompts the need for arginine supplementation (Hernandez et al., 2009; Tan et al., 2009; Tan et al., 2010) to improve growth performance and intestinal integrity in weaning piglets.

The lack of difference in protein ATTD among experimental groups could be explained by the similar diet composition. However, the lower ATTD of DM (two percentage units) in the SM diet may be as the result of the greater content of SM in neutral detergent fibre (NDF) than in SBM (Aguilera et al., 2014). The higher E digestibility of the SBM diet compared with the SM diet could be for the same reason (richness of NDF in $\mathrm{SM}$ ), and the greater content of corn oil, which is a source of highly digestible energy. Normally, pig diets have approximately $3 \mathrm{~g}$ phytic $\mathrm{P} / \mathrm{kg}$ feed (Selle \& Ravindran, 2008). Vegetable $\mathrm{P}$ represented approximately $68 \%(4 \mathrm{~g} / \mathrm{kg})$ in the SM diet and $59 \%(3 \mathrm{~g} / \mathrm{kg})$ in the SBM diet. The higher amount of phytic P in the SM diet is because of its high level of phytate (Selle et al., 2012; Aguilera et al., 2014). The rate of increase of $P$ ATTD in the SM (24.4 percentage units) and SBM (31.3 percentage units) diets represents $1.4 \mathrm{~g}(0.14 \%)$ of $P$ released by phytase in the SM diets and $1.6 \mathrm{~g}(0.16 \%)$ of $P$ released in the SBM diets. These values are similar to the amount of $\mathrm{P}$ that is normally diminished in diets supplemented with phytase (Selle \& Ravindran, 2008). This amount ( $1.5 \mathrm{~g} \mathrm{P}$ released $/ \mathrm{kg}$ feed) is equivalent to the release of $50 \%$ of phytate-bound $P$ in diets containing $3.0 \mathrm{~g} / \mathrm{kg}$ phytate-P. The $P$ equivalency value of phytase then becomes $1.5 \mathrm{~g} / \mathrm{kg}$ phytate-inorganic $\mathrm{P}$ (Selle \& Ravindran, 2008).

The lower amount of $\mathrm{P}$ released by phytase in the SM diet compared with the SBM diet could be because soybeans contain a smaller amount of phytic acid, although the same amount of enzyme was added to the two diets. Consequently, a better enzyme : substrate ratio could be attained in the SBM diet compared with the SM diet, which allowed the enzyme to release a higher amount of P. Another possible explanation is that phytase activity varies between SM and SBM because of differences in the composition, level, and location of phytate (Dersjant-Li et al., 2015). SM contains more fibre than SBM, and its phytic acid could be closely linked to fibre (Selle \& Ravindran, 2008), which could hinder phytase efficiency. These possibilities are not mutually exclusive.

In the SM and SBM diets, $62 \%$ of $\mathrm{Ca}(3.7 \mathrm{~g} / \mathrm{kg})$ and $21.1 \%$ of $\mathrm{Ca}(1.1 \mathrm{~g} / \mathrm{kg})$, respectively, were of vegetable origin. Several authors have reported an increment of Ca ATTD when the phytase enzyme has been added to the diet (Braña et al., 2006; Almeida et al., 2013) because Ca is chelated by phytic acid, regardless of its original form (Woyengo \& Nyachoti, 2013). When phytase hydrolyses phytic acid, it releases the chelated $\mathrm{Ca}$, making it available for the pigs to use.

\section{Conclusion}

The findings of this study confirm that SM could be used as an alternative protein source for weaned piglets and could increase the amount of digestible arginine levels in a natural and practical way. Even in starter diets that are characterized by low levels of phytic P, phytase increased P and Ca ATTD, allowing the reduction of $\mathrm{P}$ mineral supplementation in the diet.

\section{Acknowledgments}

This study was partially supported by the Autonomous University of Querétaro and National Research Institute of Forestry, Crop, and Livestock of Mexico. DSM Nutritional Products, México, provided the Ronozyme ${ }^{\circledR}$ enzyme used in this experiment.

\section{Authors' Contributions}

GML and TCRS conceived, designed, and analysed the experiment; KEG supervised animal management; $A A B$ and ERR carried out laboratory analysis. All authors drafted, read, and approved the final manuscript.

\section{Conflict of Interest Declaration}

The authors declare that they have no competing interests.

\section{References}

Aguilera, B.A., Reis de Souza, T.C., Mariscal-Landín, G., Guerrero, C.M.J., Escobar, G.K., Bernal, S.M.G. \& García, G.T., 2014. Morphophysiological adaptations of the gastrointestinal tract in piglets fed a sesame meal or soybean meal diet. Am. J. Anim. Vet. Sci. 9, 28-35. 
Almeida, F., Sulabo, R.C. \& Stein, H.H., 2013. Effects of a novel bacterial phytase expressed in Aspergillus Oryzae on digestibility of calcium and phosphorus in diets fed to weanling or growing pigs. J. Anim. Sci. Biotechnol. 4, 8.

AOAC, 2000. Official Methods of Analysis. Assoc. Offic. Anal. Chem., Arlington, VA. USA. pages

Avilés, R.E.D., Espinosa, G.J.A., Rentería, F.J.A., Mejía, G.C.A., Mariscal, L.G. \& Cuarón, I.J.A., 2009. Disponibilidad de ingredientes no tradicionales con potencial de ser usados en la alimentación de cerdas gestantes en el Bajío mexicano. Vet. Méx. 40, 357-370.

Braña, D., Ellis, M., Castañeda, E., Sands, J. \& Baker, D., 2006. Effect of a novel phytase on growth performance, bone ash, and mineral digestibility in nursery and grower-finisher pigs. J. Anim. Sci. 84, 1839-1849.

CIOMS, 1985. International guiding principles for biomedical research involving animals. In: Organization, W.H. (Ed.), The development of science-based guidelines for laboratory animal care - NCBI Bookshelf, Geneva.

Dersjant-Li, Y., Awati, A., Schulze, H. \& Partridge, G., 2015. Phytase in non-ruminant animal nutrition: a critical review on phytase activities in the gastrointestinal tract and influencing factors. J. Sci. Food Agric. 95, 878-896.

Diario Oficial de la Federación, 2001. Especificaciones técnicas para la producción, cuidado y uso de los animales de laboratorio. Norma Oficial Mexicana NOM-062-ZOO-1999. Diario Oficial de la Federación.

Fan, M.Z., Sauer, W.C., Hardin, R.T. \& Lien, K.A., 1994. Determination of apparent ileal amino acid digestibility in pigs: Effect of dietary amino acid level. J. Anim. Sci. 72, 2851-2859.

Gilani, G.S., Chao, W.X. \& Cockell, K.A., 2012. Impact of antinutritional factors in food proteins on the digestibility of protein and the bioavailability of amino acids and on protein quality. Br. J. Nutr. 108 S315-S332.

Hara, H., Akatsuka, N. \& Aoyama, Y., 2001. Non-essential amino acids play an important role in adaptation of the rat exocrine pancreas to high nitrogen feeding. J. Nutr. Biochem. 12, 450-457.

Harper, K., Robust single method determination of major and trace elements in foodstuffs using the Thermo Scientific iCAP 6000 Series ICP. In: Series, F. (Ed.), Food Series Thermo Fisher Scientific, p. 2.

Henderson, J.H., Ricker, R.D., Bidlingmeyer, B.A. \& Woodward, C., 2000. Rapid, accurate and reproducible HPLC analysis of amino acids. Amino acid analysis using Zorbax Eclipse AAA columns and the Agilent 1100 HPLC. Agilent technologies, 10 pag. Agilent technologies home page at: www.agilent.com/chem/supplies.

Hernandez, A., Hansen, C.F., Mullan, B.P. \& Pluske, J.R., 2009. L-arginine supplementation of milk liquid or dry diets fed to pigs after weaning has a positive effect on production in the first three weeks after weaning at 21 days of age. Anim. Feed Sci. Technol. 154, 102-111.

INRA, 2002. Tables de composition et de valeur nutritive des matières premières destinées aux animaux d'élevage. Porcs, volailles, bovins, ovins, caprins, lapins, chevaux, poissons. Institut National de la Recherche Agronomique, Paris, France. 301 pages

Kim, S.W. \& Hansen, J.A., 2013. Diet Formulation and Feeding Programs. In: Chiba, L.I. (Ed.), Sustainable Swine Nutrition. Wiley-Blackwell, Auburn, Alabama, pp. 217-227.

Lei, X. \& Stahl, C., 2001. Biotechnological development of effective phytases for mineral nutrition and environmental protection. Appl. Microbiol. Biotechnol. 57, 474-481.

Lowry, O.H., Rosebrough, N.J., Farr, A.L. \& Randall, R.J., 1951. Protein measurements with the folin phenol reagent. J. Biol. Chem. 193, 265-275.

Montagne, L., Boudry, G., Favier, C., Huërou-Luron, I., Lallès, J.-P. \& Sève, B., 2007. Main intestinal markers associated with the changes in gut architecture and function in piglets after weaning. Br. J. Nutr. 97, 45-57.

Montagne, L., Cavaney, F.S., Hampson, D.J., Lallès, J.P. \& Pluske, J.R., 2004. Effect of diet composition on postweaning colibacillosis in piglets. J. Anim. Sci. 82, 2364-2374.

Myers, W.D., Ludden, P.A., Nayigihugu, V. \& Hess, B.W., 2004. Technical Note: A procedure for the preparation and quantitative analysis of samples for titanium dioxide. J. Anim. Sci. 82, 179-183.

NRC, 2012. Nutrient Requirements of Swine: Eleventh Revised Edition. The National Academies Press, Washington, DC. 424 pag. pages

Ravindran, V., Ravindran, G. \& Sivalogan, S., 1994. Total and phytate phosphorus contents of various foods and feedstuffs of plant origin. Food Chem. 50, 133-136.

Reboud, J.P., Ben Abdeljil, A. \& Desnuelle, P., 1962. Variations de la teneur en ezymes du pancréas de rat en fonction de la composition des régimes. Biochim. Biophys. Acta 58, 326-327.

Reis de Souza, T.C., Mar, B.B. \& Mariscal, L.G., 2000. Canulación de cerdos posdestete para pruebas de digestibilidad ileal: Desarrollo de una metodología. Téc. Pecu. Méx. 38, 143-150.

Reis de Souza, T.C. \& Mariscal-Landín, G., 1997. El destete, la función digestiva y la digestibilidad de los alimentos en cerdos jóvenes. Téc. Pecu. Méx. 35, 145-159.

Reis de Souza, T.C., Mariscal, L.G., Aguilera, B.A. \& Cervantes, J.G.H., 2007. Digestibilidad de la proteína y energía en dietas para lechones, complementadas con tres diferentes tipos de suero de leche deshidratado. Vet. Méx. 38, 141-151.

Reis de Souza, T.C., Mariscal, L.G. \& Barreyro, A.A., 2005. Efecto de diferentes cereales en dietas de iniciación para lechones sobre la digestibilidad de los nutrimentos y la preferencia alimentaria. Vet. Méx. 36, 11-24.

SAS version 9.2, 2008. Statistical Analysis Systems Institute User's guide. SAS Institute Inc., Cary NC, USA.

Sato, T., Maw, A.A. \& Katsuta, M., 2004. Nondestructive Near-Infrared reflectance spectroscopy analyses of the major constituents of sesame (Sesamum Indicum L.) whole seeds with different coat color. Plant Prod. Sci. 7, 363366.

Selle, P., Cowieson, A., Cowieson, N. \& Ravindran, V., 2012. Protein-phytate interactions in pig and poultry nutrition: a reappraisal. Nutr. Res. Rev. 25, 1-17.

Selle, P.H. \& Ravindran, V., 2008. Review article: Phytate-degrading enzymes in pig nutrition. Livest. Sci. 113, 99-102. 
Steel, R.G.D. \& Torrie, J.H., 1980. Principles and procedures of statistics. A Biometrical approach. McGraw-Hill New York. 663 pages

Tan, B., Li, X.G., Kong, X., Huang, R., Ruan, Z., Yao, K., Deng, Z., Xie, M., Shinzato, I., Yin, Y. \& Wu, G., 2009. Dietary I-arginine supplementation enhances the immune status in early-weaned piglets. Amino Acids 37, 323-331.

Tan, B., Yin, Y., Kong, X., Li, P., Li, X., Gao, H., Li, X., Huang, R. \& Wu, G., 2010. L-Arginine stimulates proliferation and prevents endotoxin-induced death of intestinal cells. Amino Acids 38, 1227-1235.

Woyengo, T.A. \& Nyachoti, C.M., 2013. Review: Anti-nutritional effects of phytic acid in diets for pigs and poultry current knowledge and directions for future research. Can. J. Anim. Sci. 93, 9-21.

Yamuchi, K., Samanya, M., Seki, K., ljiri, N. \& Thongwittaya, N., 2006. Influence of dietary sesame meal level on histological alterations of the intestinal mucosa and growth performance of chickens. J. Appl. Poult. Res. 15, 266-273. 